DOI: $10.19195 / 2084-5065.39 .5$

\title{
Materialnoprawne aspekty orzekania kary ograniczenia wolności
}

\author{
KAMILA MROZEK \\ Katedra Prawa Karnego Wykonawczego \\ Wydział Prawa, Administracji i Ekonomii Uniwersytetu Wrocławskiego
}

Od chwili wprowadzenia kary ograniczenia wolności do systemu środków prawnokarnej reakcji na przestępstwo kara ta kojarzona była z obowiązkiem wykonywania nieodpłatnej, kontrolowanej pracy na cele społeczne w odpowiednim wymiarze, który — w stosunku do osoby zatrudnionej - mógł być zamieniony na potrącenie odpowiedniej części wynagrodzenia za pracę. Kara ograniczenia wolności funkcjonowała w takiej postaci przez ponad 45 lat.

Poważne zmiany w obrębie przedmiotowej kary wprowadziła ustawa z dnia 20 lutego 2015 r. o zmianie ustawy - Kodeksu karnego oraz niektórych innych ustaw, która weszła w życie z dniem 1 lipca 2015 r. ${ }^{1}$ Do podstawowych elementów wpisujących się w treść kary ograniczenia wolności i wyznaczających jednocześnie stopień jej dolegliwości zaliczano:

1. obowiązek wykonywania nieodpłatnej, kontrolowanej pracy na cele społeczne;

2. obowiązek pozostawania $\mathrm{w}$ miejscu stałego pobytu lub w innym wyznaczonym miejscu, z zastosowaniem systemu dozoru elektronicznego;

3. obowiązek określony w art. $72 \S 1$ pkt 4-7a k.k.;

1 Ustawa z dnia 20 lutego 2015 r. o zmianie ustawy — Kodeks karny oraz niektórych innych ustaw, Dz.U. z 2015 r., poz. 396. 
4. potrącenie od $10 \%$ do $25 \%$ wynagrodzenia za pracę w stosunku miesięcznym na cel społeczny wskazany przez sąd.

Skazany zobowiązany był zatem do wykonywania przynajmniej jednego obowiązku z art. 34 § 1a pkt 1-3 k.k. lub potrącenia wynagrodzenia, o którym mowa w art. $34 \S 1$ a pkt 4 k.k. Elementy te, zwane również mobilnymi, mogły być orzekane osobno lub łącznie. Ustawodawca dopuszczał zatem możliwość kumulowania tychże elementów, zezwalając na wykonywanie kary ograniczenia wolności poprzez łączne zastosowanie wszystkich lub wybranych obowiązków oraz potrącenia, o których mowa w treści art. 34 1 1a k.k. Dodatkowymi, acz obligatoryjnymi elementami kary ograniczenia wolności, był określony w art. 34 $\S 2$ k.k. zakaz zmiany miejsca stałego pobytu bez zgody sądu oraz obowiązek udzielania wyjaśnień dotyczących przebiegu odbywania kary. Kodeks karny przewidywał również możliwość orzeczenia, obok kary ograniczenia wolności, zobowiązania do uiszczenia świadczenia pieniężnego z art. 39 pkt 7 k.k. lub jednego z dwóch obowiązków, mianowicie obowiązku przeproszenia pokrzywdzonego lub wykonywania ciążącego na skazanym obowiązku łożenia na utrzymanie innej osoby (art. $34 \S 3$ k.k.).

Zmiana ta miała charakter rewolucyjny, albowiem przed dniem 1 lipca 2015 r. niemożliwe było połączenie obowiązku wykonywania nieodpłatnej kontrolowanej pracy na cele społeczne z potrąceniem wynagrodzenia za pracę. Należy jednak zaznaczyć, że w nowym modelu kara ograniczenia wolności nie była obligatoryjnie łączona z obowiązkiem wykonywania pracy - praca na cele społeczne mogła być tylko jedną z form wykonywania kary ograniczenia wolności, obok innych wynikających z art. 34 § 1a k.k. Co więcej, ustawodawca wprowadził możliwość orzeczenia jej nawet bez obowiązku, o którym mowa w art. $34 \S 1$ a pkt 1 k.k.

Niezależnie jednak od ilości obowiązków jakie ciążyły na skazanym w trakcie odbywania kary ograniczenia wolności, tworzyły one jedną i niepodzielną sankcję, zaś ich liczba i rodzaj — obok okresu wykonywania kary — były wyznacznikiem stopnia jej dolegliwości ${ }^{2}$.

2 T. Sroka, Koncepcja jedności kary ograniczenia wolności w nowym modelu tej kary po nowelizacji z 20 lutego 2015 r., „Palestra” 2015, z. 7-8, s. 50. 
Każdy z wyżej opisanych elementów czynił karę ograniczenia wolności najbardziej elastyczną ze wszystkich znanych kar w kodeksie karnym i możliwą do konkretyzowania a casu ad casum ${ }^{3}$.

Po niespełna roku obowiązywania nowego modelu kary ograniczenia wolności okazało się, że nie wszystkie zaproponowane w 2015 r. rozwiązania funkcjonują prawidłowo. Dostrzeżono bowiem, że:

doświadczenia płynące z funkcjonowania systemu dozoru elektronicznego po dniu 1 lipca 2015 r., jako formy wykonywania kary ograniczenia wolności, wskazują na diametralny spadek liczby osób objętych tym systemem. [...] Zmiana ta okazała się w praktyce wysoce nieefektywna i przyniosła drastyczny spadek orzeczeń o wykonywaniu kary w systemie dozoru elektronicznego. Z tego względu dalsze stosowanie systemu dozoru elektronicznego na potrzeby wykonywania kary ograniczenia wolności może doprowadzić do zmarginalizowania tej instytucji w sferze polityki karnej ${ }^{4}$.

Analiza danych statystycznych dotyczących ilości zrealizowanych instalacji urządzeń monitorujących od dnia 1 lipca 2015 r. do marca 2016 r. istotnie potwierdza spadek liczby zakładanych urządzeń monitorujących ${ }^{5}$. Jak wynika z treści powołanego uzasadnienia, powodem takiego stanu rzeczy było najprawdopodobniej przeniesienie uprawnień do sięgania po system dozoru elektronicznego z sądów penitencjarnych na sądy orzekające w sprawie (sądy meriti). Nie przesądzając w tym miejscu ostatecznie, jaki powód faktycznie zdecydował o rzadszym stosowaniu rozwiązań, o których mowa w rozdziale VIIa k.k.w., należy spojrzeć na uwagi Sądu Najwyższego do rządowego projektu ustawy o zmianie ustawy - Kodeks karny oraz ustawy — Kodeks karny wykonawczy ${ }^{6}$. W opinii tej Sąd Najwyższy zarzuca projektodawcy, że usprawiedliwianie rażącego spadku orzeczeń o wykonywaniu kary w systemie dozoru elektronicznego wyłącznie przyporządkowaniem tegoż rozwiązania do kary ograniczenia wolności stanowi zbytnie uproszczenie i spłycenie problemu. Głębszej analizy wymaga bowiem ocena stosunku zależności

${ }^{3}$ Ibidem, s. 87.

${ }^{4}$ Uzasadnienie do rządowego projektu ustawy o zmianie ustawy — Kodeks karny oraz ustawy - Kodeks karny wykonawczy z dnia 26 stycznia 2016 r., druk nr 218.

${ }^{5} \mathrm{http}: / /$ www.dozorelektroniczny.gov.pl (dostęp: 8.08.2016).

${ }^{6}$ Opinia Sądu Najwyższego, Biuro Studiów i Analiz w sprawie rządowego projektu ustawy o zmianie ustawy - Kodeks karny oraz ustawy — Kodeks karny wykonawczy, do druku nr 218. 
pomiędzy liczbą orzekanych kar pozbawienia wolności i ograniczenia wolności w przypadku przestępstw, do których zastosowanie miały regulacje obowiązujące od dnia 1 lipca 2015 r. Nie uwzględniono również liczby postępowań karnych wszczętych po dniu wejścia w życie ustawy z dnia 20 lutego 2015 r. o zmianie ustawy - Kodeks karny oraz niektórych innych ustaw ${ }^{7}$, a także liczby postępowań zakończonych w trybie konsensualnym, zwłaszcza w trybie art. 59a k.k. Dostrzeżone braki, w ocenie Sądu Najwyższego, powodują, że rezygnacja z dozoru elektronicznego jako jednego $\mathrm{z}$ elementów wpisujących się w dotychczasową treść kary ograniczenia wolności jest przedwczesna, albowiem okres, jaki upłynął od chwili wprowadzenia w życie przedmiotowej regulacji, jest zbyt krótki, aby kategorycznie przesądzać o dysfunkcjonalności wdrożonych rozwiązań legislacyjnych.

Być może właściwym rozwiązaniem, przy założeniu przestrzegania przez sądy orzekające w postępowaniu jurysdykcyjnym nowej filozofii karania, jaką wprowadziła ustawa z dnia 20 lutego 2015 r. o zmianie ustawy — Kodeks karny oraz niektórych innych ustaw, byłoby skierowanie postępowania w przedmiocie odbywania kary ograniczenia wolności w systemie dozoru elektronicznego na drogę karno-wykonawczą. Pod rządami ustawy z dnia 7 września 2007 r. o wykonywaniu kary pozbawienia wolności poza zakładem karnym w systemie dozoru elektronicznego ${ }^{8}$ głównym inicjatorem przedmiotowego postępowania był skazany, a momentem kluczowym pozwalającym na wszczęcie tegoż postępowania był moment uprawomocnienia się wyroku skazującego na bezwzględną karę pozbawienia wolności lub też moment wydania postanowienia o zarządzeniu wykonania kary warunkowo zawieszonej.

Pozytywną opinię w zakresie projektowanej (obecnie obowiązującej już) zmiany wyraził natomiast Prokurator Generalny oraz Przewodniczący Krajowej Rady Sądownictwa ${ }^{9}$, wskazując, że:

7 Ustawa z dnia 20 lutego 2015 r. o zmianie ustawy — Kodeks karny oraz niektórych innych ustaw, Dz.U. z 2015 r., poz. 396.

8 Ustawa z dnia 7 września 2007 r. o wykonywaniu kary pozbawienia wolności poza zakładem karnym w systemie dozoru elektronicznego, Dz.U. z 2010 r., Nr 142, poz. 960 z późn. zm.

9 Opinia Prokuratora Generalnego w sprawie rządowego projektu ustawy o zmianie ustawy — Kodeks karny oraz ustawy — Kodeks karny wykonawczy, do druku nr 218; 
dotychczasowe doświadczenia wynikające ze stosowania w praktyce instytucji systemu dozoru elektronicznego pozwalają na jej jednoznacznie pozytywną ocenę, gdyż proces resocjalizacji sprawców przestępstw o niewielkim ładunku społecznej szkodliwości może następować poza zakładem penitencjarnym w warunkach samokontroli, bez zrywania więzi rodzinnych, społecznych i zawodowych. Jednocześnie taki sposób odbywania kary zapewnia korzyści systemowe w postaci oszczędności finansowych i zmniejszenia populacji skazanych w zakładach karnych.

W konsekwencji ustawą z dnia 11 marca 2016 r. o zmianie ustawy — Kodeks karny oraz ustawy — Kodeks karny wykonawczy ${ }^{10}$ — przywrócono możliwość stosowania dozoru elektronicznego jako formy wykonywania kary pozbawienia wolności, uchylając tym samym w art. 34 $\S$ 1a-pkt 2 k.k. Reasumując, od dnia 15 kwietnia 2016 r., tj. od dnia wejścia w życie przedmiotowej ustawy dozór elektroniczny nie stanowi już jednego z podstawowych elementów wpisujących się w treść kary ograniczenia wolności.

Już w pierwszym miesiącu obowiązywania ustawy nowelizującej liczba zrealizowanych instalacji urządzeń monitorujących w ramach systemu dozoru elektronicznego wzrosła o ponad 20\% (marzec 2016 r. 430, kwiecień 2016 r. - 519, maj 2016 r. - 577).

Warto również zwrócić uwagę, że ustawa z dnia 11 marca 2016 r. o zmianie ustawy - Kodeks karny oraz ustawy - Kodeks karny wykonawczy — wprowadza przepisy intertemporalne, które rozwiązują problemy okresu przejściowego. Zgodnie bowiem z brzmieniem art. 4 powołanej ustawy w stosunku do osób, które przed dniem wejścia w życie niniejszej ustawy odbywają karę ograniczenia wolności polegającą na obowiązku pozostawania $\mathrm{w}$ miejscu stałego pobytu lub w innym wyznaczonym miejscu z zastosowaniem dozoru elektronicznego, oraz w stosunku do osób skazanych, wobec których orzeczono przed dniem wejścia w życie niniejszej ustawy choćby nieprawomocnie karę ograniczenia wolności polegającą na obowiązku pozostawania w miejscu stałego pobytu lub w innym wyznaczonym miejscu, z zastosowaniem dozoru elektronicznego, stosuje się przepisy dotychczasowe.

Opinia Przewodniczącego Krajowej Rady Sądownictwa w sprawie rządowego projektu ustawy o zmianie ustawy - Kodeks karny oraz ustawy — Kodeks karny wykonawczy, do druku nr 218.

${ }^{10}$ Ustawa z dnia 11 marca 2016 r. o zmianie ustawy - Kodeks karny oraz ustawy — Kodeks karny wykonawczy, Dz.U. z 2016 r., poz. 428. 
Warto zauważyć, że ustawodawca zdecydował o jeszcze większej ingerencji w aktualny kształt kary ograniczenia wolności, eliminując możliwość orzekania obowiązków, o których mowa w art. $72 \S 1$ pkt 4-7a k.k., w formie elementu podstawowego ${ }^{11}$. Obowiązki te, wraz z wejściem w życie przedmiotowej nowelizacji, przekształcono w akcesoryjny element kary ograniczenia wolności i w konsekwencji przeniesiono do katalogu, o którym mowa w art. $34 \S 3$ k.k. W uzasadnieniu do rządowego projektu powołanej ustawy wskazywano, że stopień dolegliwości, a tym samym element represyjności reakcji karnej, jest w przypadku obowiązków, o których mowa w art. 72 k.k., niewspółmierny do stopnia społecznej szkodliwości popełnionego przez sprawcę czynu. Obowiązki te - w ocenie ustawodawcy — nie posiadały zatem charakteru represyjnego, a jedynie probacyjny ${ }^{12}$.

Rezygnacja z tej formy wykonania kary ograniczenia wolności zyskała pełną aprobatę Prokuratora Generalnego ${ }^{13}$.

Elementy treściowe kary ograniczenia wolności określa art. 34 $\S 1 \mathrm{a}-2$ k.k. W literaturze przedmiotu wskazuje się na dwie grupy tychże elementów: obligatoryjne (art. $34 \S 2$ k.k.) oraz względnie obligatoryjne (art. 34 § 1a k.k.).

Zgodnie z brzmieniem art. 34 § 2 k.k. w czasie odbywania kary ograniczenia wolności skazany nie może bez zgody sądu zmieniać miejsca stałego pobytu oraz zobowiązany jest do udzielania wyjaśnień dotyczących przebiegu odbywania kary ${ }^{14}$. Obowiązki te nakładane są na skazanego z mocy samego prawa, co powoduje, że nie mogą one być modyfikowane ani redukowane przez sąd w wyroku skazującym. Stanowią one

11 Ustawa z dnia 11 marca 2016 r. o zmianie ustawy - Kodeks postępowania karnego oraz niektórych innych ustaw, Dz.U. z 2016 r., poz. 437.

12 Uzasadnienie do rządowego projektu ustawy o zmianie ustawy - Kodeks postępowania karnego oraz niektórych innych ustaw z dnia 27 stycznia 2016 r., druk nr 207.

13 Opinia Prokuratora Generalnego w sprawie rządowego projektu ustawy o zmianie ustawy - Kodeks postępowania karnego oraz niektórych innych ustaw, do druku nr 207, s. 7.

${ }^{14}$ Celem zakazu zmiany miejsca stałego pobytu jest zapewnienie właściwego nadzoru sądowego nad wykonywaniem kary ograniczenia wolności. Zakaz ten zapobiega także nieprawidłowościom w wykonywaniu obowiązku pracy, które mogą nastapić w sytuacji, gdy skazany przeniesie się w miejsce odległe od jej wykonywania, zob. Kodeks karny. Komentarz, red. A. Grześkowiak, K. Wiak, wyd. 4, Warszawa 2016. 
stały (obligatoryjny) element treściowy przedmiotowej kary. Orzekając karę ograniczenia wolności, sąd nie ma zatem obowiązku powoływania ich w wyroku skazującym. Niemniej wyszczególnienie ich w treści orzeczenia pozwala na uniknięcie niejednoznaczności co do tego, jakie konkretnie obowiązki i zakazy ciążą na skazanym. Obowiązek precyzyjnego określenia miejsca stałego pobytu skazanego odbywającego karę ograniczenia wolności - na podstawie jego pisemnego oświadczenia - mógłby także umożliwić skontrolowanie naruszenia zakazu zmiany miejsca stałego pobytu bez zgody sądu, o którym mowa w treści art. 34 $\S 2$ pkt 1 k.k. ${ }^{15}$.

Do obowiązków względnie obligatoryjnych ustawodawca zaliczył obecnie:

- obowiązek wykonywania nieodpłatnej, kontrolowanej pracy na cele społeczne;

— potrącenie od $10 \%$ do $25 \%$ wynagrodzenia za pracę w stosunku miesięcznym na cel społeczny wskazany przez sąd.

Względnie obligatoryjny charakter tych rygorów wyraża się w tym, że sąd, orzekając karę, musi zastosować przynajmniej jeden z nich, przy czym ustawodawca pozostawił możliwość orzekania ich osobno lub łącznie. Mimo tego względnego charakteru wspomniane rygory mają zasadnicze znaczenie dla treści kary ograniczenia wolności, co wynika wprost $\mathrm{z}$ brzmienia art. 34 § 1a k.k. ${ }^{16}$ Brak bowiem wskazania w treści wyroku choćby jednego z obowiązków, o których mowa w powołanym przepisie, czyni orzeczoną karę niewykonalną i stanowi rażące naruszenie przepisów prawa materialnego mających istotny wpływ na treść wyroku ${ }^{17}$.

Orzekając karę ograniczenia wolności, sąd powinien zatem precyzyjnie określić wymiar kary oraz wskazać jej względnie obligatoryjny

15 Zmiany miejsca stałego pobytu nie stanowi każde, w tym krótkotrwałe, opuszczenie tego miejsca (np. w celu dotarcia do miejsca pracy, zrobienia zakupów czy odwiedzin znajomych), a tylko takie opuszczenie, które skutkuje tym, że dotychczasowe miejsce stałego pobytu staje się nieaktualne, a inne, nowe miejsce, nabiera cech miejsca stałego pobytu, E. Zielińska, Zakaz zmiany miejsca pobytu oraz zakaz sprawowania funkcji w organizacjach społecznych — zwiqzane z karq ograniczenia wolności, „Nowe Prawo" 1973, nr 4, s. 562.

16 R. Stefański, R. Giętkowski, Kodeks karny. Komentarz, wyd. 15, Warszawa 2016.

17 Wyrok Sądu Najwyższego z dnia 5 marca 2008 r., V KK 453/07, OSNwSK 2008, Nr 1, poz. 542. 
element treściowy (lub oba te elementy), konkretyzując go w następujący sposób: w przypadku obowiązku wykonywania nieodpłatnej, kontrolowanej pracy na cele społeczne - podając godzinowy wymiar tego obowiązku w stosunku miesięcznym, a w razie potrąceń z wynagrodzenia za pracę - określić wysokość potrąceń i ich cel. W razie pominięcia przez sąd którejkolwiek z wymienionych kwestii wyrok skazujący na karę ograniczenia wolności będzie niewykonalny, a wady tej nie da się usunąc w postępowaniu wykonawczym ${ }^{18}$.

Wymierzając karę ograniczenia wolności, sąd może orzec świadczenie pieniężne wymienione $\mathrm{w}$ art. 39 pkt 7 k.k. lub obowiązki, o których mowa w art. $72 \S 1$ pkt 2-7a k.k. Zauważyć zatem należy, że ustawą z dnia 11 marca 2016 r. o zmianie ustawy - Kodeks karny oraz ustawy - Kodeks karny wykonawczy - ustawodawca zdecydował o rozszerzeniu katalogu obowiązków orzekanych fakultatywnie obok kary ograniczenia wolności. Oprócz dotychczasowych obowiązków, polegających na przeproszeniu pokrzywdzonego oraz wykonywaniu ciążącego na skazanym obowiązku łożenia na utrzymanie innej osoby, sąd może orzec dodatkowo obowiązek:

- wykonywania pracy zarobkowej, do nauki lub przygotowania się do zawodu;

- powstrzymania się od nadużywania alkoholu lub używania innych środków odurzających;

— poddania się terapii uzależnień; edukacji;

— poddania się terapii, w szczególności psychoterapii lub psycho-

- uczestnictwa w oddziaływaniach korekcyjno-edukacyjnych;

- powstrzymania się od przebywania w określonych środowiskach lub miejscach;

- powstrzymania się od kontaktowania się z pokrzywdzonym lub innymi osobami w określony sposób albo zbliżania się do pokrzywdzonego lub innych osób.

Zauważyć przy tym należy, że art. $74 \S 2$ k.k., który znajduje odpowiednie zastosowanie na podstawie art. $35 \S 4$ k.k. do orzekania obo-

18 Wyrok Sądu Najwyższego z dnia 4 sierpnia 2011 r., II KK 18/11, Lex nr 960520; Wyrok Sądu Najwyższego z dnia 16 stycznia 2014 r., V KK 336/13, Lex nr 1418903. 
wiązków z art. $72 \S 1$ pkt 2-7a k.k., zezwala na ustanawianie, rozszerzanie lub zmianę obowiązków z art. $72 \S 1$ pkt 3-8 k.k. albo zwolnienie od ich wykonania, jeżeli względy wychowawcze za tym przemawiają. Enumeratywne wyliczenie obowiązków podlegających modyfikacji w trakcie ich wykonywania wyłącza możliwość stosowania powyższej zasady do obowiązku przeproszenia pokrzywdzonego, o którym mowa w treści art. $72 \S 1$ pkt 2 k.k.

Czas i sposób wykonania nałożonych obowiązków sąd określa po wysłuchaniu skazanego. Nałożenie obowiązku w postaci poddania się terapii uzależnień oraz poddania się terapii, w szczególności psychoterapii lub psychoedukacji, wymaga uprzedniej zgody skazanego.

Istotnej zmianie uległ również wymiar kary ograniczenia wolności. Obecnie kara ograniczenia wolności trwa najkrócej miesiąc, najdłużej 2 lata. Wymierza się ją w miesiącach i latach. Górną granicę kary ograniczenia wolności określono jednolicie w niemal wszystkich wypadkach, w których możliwe jest jej orzeczenie. Tym samym maksymalny wymiar 2 lat ograniczenia wolności dotyczy kary przewidzianej jako sankcja za przestępstwo stypizowane w części szczególnej kodeksu karnego, kary ograniczenia wolności nadzwyczajnie obostrzonej oraz kary łącznej orzekanej na podstawie art. $86 \S 1$ k.k. ${ }^{19}$

Treść kary ograniczenia wolności - na nowo ukształtowana ustawą z dnia 20 lutego 2015 r. — została istotnie zmieniona kolejnymi zmianami zawartymi w dwóch ustawach z dnia 11 marca 2016 r. Uchwalenie tych ostatnich spowodowało ponowne przemodelowanie koncepcji kary ograniczenia wolności. Powrócono zatem — w znacznej części — do rozwiązań obowiązujących przed wprowadzeniem reformy prawa karnego z 2015 r. Przedmiotowa modyfikacja prowadzi w konsekwencji do przyjęcia węższej koncepcji treści tej kary. Ta, w sumie trzykrotna zmia-

19 Przepis art. 16 ust. 1 pkt 2 ustawy z dnia 20 lutego 2015 r. przewiduje sytuację, kiedy kara ograniczenia wolności może być orzeczona w wymiarze przekraczającym 2 lata. W sprawach zakończonych prawomocnym wyrokiem przed 1 lipca 2015 r., w których orzeczono karę pozbawienia wolności z warunkowym zawieszeniem jej wykonania i nie zarządzono wykonania kary, sąd, na wniosek skazanego, jeżeli cele kary zostaną w ten sposób spełnione i jeżeli dochody skazanego, jego stosunki majątkowe lub możliwości zarobkowe uzasadniają przekonanie, że nie uiści grzywny, może zamienić karę pozbawienia wolności na karę ograniczenia wolności w formie obowiązku z art. $34 \S 1 \mathrm{a}$ pkt 1 k.k. Wówczas kara ograniczenia wolności nie może trwać dłużej niż 4 lata. 
na przepisów w obrębie przedmiotowej kary, wywoła z pewnością wiele komplikacji w praktyce jej stosowania, zwłaszcza na tle problemu koncentrującego się wokół treści kary ograniczenia wolności oraz kwestii kolizji ustaw w czasie.

\section{Substantive law aspects of imposing the penalty of restriction of liberty}

\section{Summary}

Numerous changes introduced within the criminal law have had a significant impact on the final model of the penalty of restriction of liberty. The measures adopted in 2015, following the general reform of the criminal law, have turned out to be rather ineffective. Thus, certain steps have been taken to re-model the penalty of restriction of liberty, which, to a large extent meant returning to previous solutions. This paper is primarily focused on analysing subsequent amendments within the substantive criminal law related to the penalty of restriction of liberty, with particular focus on the amendments introduced in 2016 .

Keywords: penalty of restriction of liberty, electronic surveillance, community service, deduction from wages. 